\title{
Przestrzenie Przekładu 3 - międzynarodowa konferencja zorganizowana przez Insty- tut Filologii Wschodniosłowiańskiej Uniwersytetu Śląskiego w Katowicach, Sosnowiec, 26-27.10.2017 (sprawozdanie)
}

D0I: http://dx.doi.org/10.12775/RP.2018.019

W dniach 26-27 października 2017 roku w budynku Wydziału Filologicznego w Sosnowcu odbyła się konferencja Przestrzenie Przekładu 3, organizowana cyklicznie przez Instytut Filologii Wschodniosłowiańskiej Uniwersytetu Śląskiego w Katowicach. Do wzięcia udziału w obradach zaproszono filologów różnych specjalności, m.in. rusycystów, slawistów, anglistów, germanistów, romanistów. W Komitecie naukowym znalazły się dr hab. prof. UŚ Jolanta Lubocha-Kruglik i dr hab. Oksana Małysa. Zgodnie z założeniem Organizatorek, konferencja Przestrzenie Przekładu ma być okazją do spotkania traduktologów, którzy reprezentują różne ośrodki w kraju i za granicą. Niezaprzeczalną zaletą konferencji jest duża ilość prelegentów oraz „szerokie ujęcie tematu”, odzwierciedlone w nazwie konferencji. Umożliwia ono zaprezentowanie różnorodnych wyników badań, pochodzących z odmiennych języków, specjalności, podejść metodologicznych, a także pozwala na interdyscyplinarne ujęcie tematu.

Dzięki szerokiej formule konferencji szansę na przedstawienie referatów mieli zarówno uczestnicy zajmujący się zagadnieniem przekładu z teoretycznego, jak i praktycznego punktu widzenia. Atutem konferencji było zaproszenie do udziału w obradach studentów (zwolnionych z opłaty konferencyjnej), którzy mieli szansę wygłoszenia swojego referatu, a tym samym zaprezentowania własnego punktu widzenia oraz skorzystania z rad i uwag specjalistów w dziedzinie traduktologii.

Obrady dotyczyły przekładu literackiego, nieliterackiego oraz dydaktyki tłumaczenia i odnosiły się do następujących bloków tematycznych: przekład - zagadnienia ogólne, przekład specjalistyczny, przekład ustny i audiowizualny, przekład artystyczny, tłumacz i jego dzieło, zjawiska gramatyczne w przekładzie, dydaktyka przekładu, studenci o przekładzie. Warto podkreślić, iż uczestnicy konferencji z zagranicy mieli możliwość wystąpienia online. Językami roboczymi konferencji były: język polski i język rosyjski.

W dniu 26 października 2017 roku obrady plenarne rozpoczął prof. zw. dr hab. Marian Kisiel z Uniwersytetu Śląskiego w Katowicach, wygłaszając 
referat pt. „Belladonna” Nikołaja Gronskiego. O polskim przekładzie Kazimierza Andrzeja Jaworskiego. Następnie prof. UP dr hab. Aurelia Kotkiewicz oraz dr Renata Niziołek (Uniwersytet Pedagogiczny im. KEN w Krakowie) wystąiły z referatem zatytułowanym Biesy w Moskwie. O polskim i francuskim tłumaczeniu powieści „Mistrz i Małgorzata” Michaiła Buthakowa. Obrady plenarne zamknął referat dr hab. Moniki Płużyczki z Uniwersytetu Warszawskiego na temat Eyetracking $w$ badaniach procesu ttumaczenia. Parametry aktywności wzrokowej jako indykatory procesów mentalnych tłumacza. Wystąpienia plenarne od razu wprowadziły słuchaczy w rozległą „przestrzeń przekładu”, poruszając zagadnienia tłumaczenia z języka rosyjskiego na język polski i język francuski oraz wskazując możliwość zastosowania takich technik jak okulografia w badaniach dotyczących procesów mentalnych tłumacza w procesie przekładu.

Po przerwie kawowej rozpoczęły się obrady w sekcjach. Jednocześnie w czterech salach przedstawiono łącznie szesnaście wystąpień sklasyfikowanych kolejno w sekcjach: przekład artystyczny, dydaktyka przekładu, przekład specjalistyczny oraz studenci o przekładzie. Obrady w sekcji poświęconej przekładowi artystycznemu prowadziła dr hab. prof. UP Aurelia Kotkiewicz. Swoje referaty przedstawili następujący prelegenci: dr hab. Joanna Warmuzińska-Rogóż (Uniwersytet Śląski w Katowicach), Przyczynek do refleksji nad procesem wydawniczym dzieł literackich $w$ tłumaczeniu na przykładzie quebeckich „Dzieci stamtąd” Arlette Cousture w polskim przekładzie; prof. UŚ Jolanta Lubocha-Kruglik, dr hab. Oksana Małysa (Uniwersytet Śląski w Katowicach), O polskim przekładzie powieści „T” Wiktora Pielewina; канд. фил. наук Сергей Сидоренко (Национальный авиационный университет, Киев), Поликультурный мир романа Марии Матиос „Солодка Даруся” в оригинале и переводе oraz w wystąpieniu online: канд. фил. наук Анастасия Уржа (Московский Государственный Университет им. М. В. Ломоносова) „...сказал он” или „...вздохнул он”? Интерпретация глаголов, вводящих речь, в русском художественном переводе. Przewodniczącą obrad w sekcji: dydaktyka przekładu była dr hab. Monika Płużyczka. Wysłuchaliśmy następujących wystąpień: dr Kseni Gałuskinej (Uniwersytet Śląski w Katowicach), Praca $w$ zespole tlumaczeniowym - problemy dydaktyczne; dr Piotra Michałowskiego (Uniwersytet Warszawski), Tłumaczenie selektywno-streszczające - założenia dydaktyczne oraz recepcja wśród studentów; dr Ewy Zwierzchoń-Grabowskiej (Uniwersytet Warszawski), Nowe technologie $w$ dydaktyce przekładu oraz mgr Justyny Sekuły (Uniwersytet Pedagogiczny im. KEN w Krakowie), Platforma Moodle i metoda WebQuest'u, czyli innowacyjne zajęcia z przekładu specjalistycznego. Natomiast w sekcji przekład 
specjalistyczny, prowadzonej przez prof. zw. dr hab. Sambora Gruczę, wyniki swoich badań przedstawiło czterech mówców: dr hab. Lubomir Hampl (Akademia Techniczno-Humanistyczna), Językowy obraz świata awifauny w słowiańskiej frazeologii i tekstach biblijnych; dr Ewa Białek (Uniwersytet Marii Curie-Skłodowskiej w Lublinie), Translaty nieopisane - badania empiryczne; dr Joanna Janusz (Uniwersytet Śląski w Katowicach), Teoria Skoposu w przekładzie włoskich tekstów specjalistycznych $z$ zakresu prawa karnego. Studium jednego przypadku oraz dr Ewa Michalska (Akademia Techniczno-Humanistyczna), Przekład terminów prawnych z języka czeskiego i / lub słowackiego na język polski (na przykładzie zapożyczeń łacińskojęzycznych). W ostatniej sekcji, w której Organizatorzy oddali głos studentom, dr Anna Szczęsny przewodniczyła następującym wystąpieniom: mgr Zofii Małysy (Uniwersytet Jagielloński w Krakowie), Kulinarny trójkąt na trawie. Kwestia tłumaczenia tytułu obrazu Édouarda Maneta Le Déjeuner sur l'herbe; mgr Dawida Adamczyka (Uniwersytet Śląski w Katowicach), О характеристике терминов трудового права и их переводе (на материале трудовых кодексов Российской Федерации и Республики Польща); lic. Dawida Bronowskiego (Uniwersytet Śląski w Katowicach), „Таможенный кодекс Таможенного союза" и его предпереводческий анализ oraz wystąpieniu online: mgr Agaty Joanny Kornackiej (Uniwersytet Warszawski), Nikt nie może dwóm panom służyć?, czyli o władzy w przekładzie poezji na podstawie polskiego tłumaczenia argentyńskiego tomu poetyckiego pt. „Ensayo sobre el poder” Liliany Lukin. Po owocnych obradach rozmowy przeniosły się na przerwę kawową.

W kolejnym bloku obrad konferencyjnych czternastu prelegentów zostało podzielonych na trzy sekcje: przekład artystyczny; dydaktyka przekładu, tłumacz i jego dzieło oraz przekład specjalistyczny. Dr hab. Joanna Warmuzińska-Rogóż była przewodniczącą sekcji przekładu artystycznego, w której wystąpili: dr Małgorzata Ślarzyńska (Uniwersytet Kardynała Stefana Wyszyńskiego w Warszawie), W przestrzeni tekstowej $i$ metatekstowej: polskie przekłady Alby De Céspedes; dr Aleksandra Jackiewicz (Uniwersytet Warszawski) „Moja poezja niczego nie tłumaczy”. Różewicza portret w przekładach na język hiszpański; mgr Łukasz Gęborek (Uniwersytet Śląski w Katowicach), Синкретизм слов как способ выражения юмора. Переводческий acneкm oraz mgr Maciej Małek (Uniwersytet Śląski w Katowicach), O historii przekładu tekstów dramatycznych. W sekcji poświęconej dydaktyce przekładu oraz tłumaczowi i jego dziełu, w której przewodniczącą była dr hab. Oksana Małysa, swoje referaty przedstawiły następujące osoby: канд. фил. наук Сирье Купп-Сазонов (Тартуский университет), Переводят ли мужчины и женщины действительно по-разному? (на материале 
четырех эстонских переводов повести А. Н. Толстого „Золотой ключик, или Приключения Буратино"); dr Patrycja Bobowska-Nastarzewska (Uniwersytet Mikołaja Kopernika w Toruniu), Oprzekładalności idiolektu filozofagarść autorskich refleksji o przekładzie tekstów filozoficznych na przykładach; dr Anna Szczęsny (Uniwersytet Warszawski), Nazwy własne $w$ tłumaczeniu pisemnym - spojrzenie dydaktyka; dr Katarzyna Tymoszuk (Uniwersytet Marii Curie-Skłodowskiej w Lublinie), Tłumaczenie tekstów piosenek Spaceman Spiff jako element nauczania przekładu. Wybrane problemy i strategie oraz w wystąpieniu online: канд. фил. наук Ольга Кузяева (Удмуртский государственный университет), Обучение студентов языкового вуза основам аудиовизуального перевода. W ostatniej sekcji pierwszego dnia obrad, poświęconej przekładowi specjalistycznemu, przewodniczącą była dr hab. prof. UŚ Jolanta Lubocha-Kruglik, a prelegentami: dr Anna Bonek (Uniwersytet Warszawski), Wykładnia translacyjna tekstów z zakresu prawa administracyjnego; dr Anna Kizińska (Uniwersytet Warszawski), Tłumaczenie nieprzystających terminów prawa rodzinnego - studium przypadku; mgr Katarzyna Banaś-Sieradzka (Uniwersytet Śląski w Katowicach), Sposoby tłumaczenia tekstu technicznego na przykładzie specyfikacji technicznych związanych $z$ oświetleniem samochodowym; mgr Magdalena Łomzik (Uniwersytet Pedagogiczny im. KEN w Krakowie), Przekład nazw instytucji w tłumaczeniu poświadczonym $w$ teorii i praktyce oraz dr Michał Akartel (Uniwersytet Pedagogiczny im. KEN w Krakowie), K вопросу о переводе языкового подстандарта (на материале русских и польских имен собственных как нарицательных).

W drugim dniu konferencji obrady rozpoczęły się jednocześnie w trzech sekcjach: przekład artystyczny, przekład - zagadnienia ogólne oraz studenci o przekładzie. Sekcję przekład artystyczny poprowadził prof. zw. dr hab. Henryk Fontański. Wystąpili w niej: dr hab. Małgorzata Borek (Uniwersytet Śląski w Katowicach), Poezja Afanasija Feta w przekładzie na język polski; dr Ewa Drab (Uniwersytet Śląski w Katowicach), Przeobrażenie elementów kulturowych w „Nigdziebądż” Neila Gaimana a przekład urban fantasy; dr Hanna Makurat (Uniwersytet Gdański), Ominięcie i ekspozycja - dwie strategie stosowane przez tłumaczy tekstów na język kaszubski oraz mgr Małgorzata Bachan-Kołodziejska (Uniwersytet Jagielloński w Krakowie), „Rosyjski kochanek" Marii Nurowskiej w tłumaczeniu na język rosyjski. Dr Ewa Białek oraz dr Anna Szczęsny poprowadziły sekcję zatytułowaną przekład - zagadnienia ogólne, w której mówcami byli: prof. Pol. Śl. dr hab. Piotr Mamet (Politechnika Śląska w Gliwicach), dr Gabriela Wilk (Uniwersytet Śląski w Katowicach), „Miłosne" idiomy Agenta 007 w tłumaczeniu na język polski i rosyjski; mgr 
Ilona Delekta (Uniwersytet Śląski w Katowicach), Eufemizmy na rynku pracy, czyli jeszcze o poprawności politycznej. Rozważania tłumacza; dr Grair Magakian (Uniwersytet Śląski w Katowicach), Obciązenie kulturowe na przykładzie „Pieśni na dzień Wardawaru” Grigora z Nareku oraz mgr Sławomir Smugowski (Uniwersytet Śląski w Katowicach), Ochrona danych osobowych w pracy tłumacza. Natomiast sekcji: studenci o przekładzie przewodniczył dr Maciej Walczak. Swoje wystąpienia przedstawiły następujące osoby: mgr Aleksandra Wojnarowska (Uniwersytet Śląski w Katowicach), Wyrazy realia a przekład współczesnych bułgarskich przepisów kulinarnych na język polski; lic. Michał Pyzik (Uniwersytet Śląski w Katowicach), Kilka słów o przekładzie feministycznym; Ольга Белоусова (Национальный авиационный университет, Киев), Соответствие интернет-версии английского языка учебным материалам, используемым в процессе подготовки студентов специальности перевод oraz w wystąpieniu online: Yuliya Matysiak (Uniwersytet Łódzki), „Polusia, córka kołodzieja czyli wolność oswobodzona. Opera tragiczna w 2 aktach", z rosyjskiego na polski przetłumaczona W. I. Marewicza - oryginat czy tłumaczenie. Ostatni blok niniejszej konferencji stanowiły obrady w trzech sekcjach: przekład artystyczny, zjawiska gramatyczne w przekładzie oraz studenci o przekładzie. Pierwszą sekcję poprowadziły dr hab. Anna Zych i dr Małgorzata Ślarzyńska, a prelegentkami były: dr Anna Głogowska (Uniwersytet Warszawski), Od rosyjskiej "fiełosofii” do polskiej „chwilozofii”. Etymologia ludowa w tłumaczeniu; mgr Weronika Sztorc (Uniwersytet Warszawski), Co tłumacze mówią o swojej pracy? Uwagi o warsztacie tłumacza $w$ przypisach do tekstów literackich oraz w wystąpieniu online: магистр Ганна Филатова (Московский государственный университет им. М. В. Ломоносова), Влияние переводного текста на восприятие персонажа: как переводчик меняет образ героя. Dr hab. Małgorzata Borek przewodniczyła obradom w sekcji poświęconej zjawiskom gramatycznym w przekładzie. Swoje wystąpienia przedstawiły następujące osoby: dr Marta Malanowska-Statkiewicz (Uniwersytet Opolski), Wyrazy dźwiękonaśladowcze w czeskim i polskim przekładzie Harry'ego Pottera; канд. фил. наук Людмила Галій (Национальный авиационный университет, Киев), Перевод многокомпонентных местоименных конструкиий с подлежащим предложением с английского на русский и украинский языки oraz Лариса Климова (Волгоградская государственная академия последипломного образования), Особенности перевода немеиких и русских артионимов. Przewodniczącą sekcji studenci w przekładzie była dr Gabriela Wilk, mówcami zaś: Aleksandra Mazur (Uniwersytet Śląski w Katowicach), Udomowienie i egzotyzacja w stużbie humoru; lic. Tomasz Drozdziński (Uniwersytet Gdański), Nazwy 
własne i skrótowce $w$ ukraińskich tekstach wojskowych - wybrane przykłady $z$ perspektywy tłumacza oraz mgr Konrad Wójcik (Uniwersytet Śląski w Katowicach), Brzmienie języka polskiej i rosyjskiej wersji poematu „Bal w operze”.

Pojemna formuła konferencji obejmująca różnorodne tematy wystąpień i liczna obecność uczestników (także z wystąpieniami online), unaoczniona w powyższym zestawieniu prelegentów, oraz żywa pasjonująca dyskusja nad istotnymi zagadnieniami przekładu, wskazują, iż potrzebne są tego typu spotkania specjalistów i adeptów sztuki tłumaczenia. W przypadku konferencji Przestrzenie Przekładu 3 w Sosnowcu bez wątpienia na szczególną uwagę zasługuje niepowtarzalny nastrój stworzony przez Organizatorów, w tym szczególnie dr hab. prof. UŚ Jolantę Lubochę-Kruglik i dr hab. Oksanę Małysę, które niezwykle ciepło i życzliwie przyjęły wszystkich uczestników. Przyjazna atmosfera panująca $w$ trakcie konferencji oraz otwarta postawa Organizatorów stworzyły warunki do wygłaszania konstruktywnej krytyki, pozwalając tym samym na ożywioną wymianę zdań w czasie dyskusji w sekcjach, a także na owocne rozmowy w kuluarach oraz w czasie bankietu.

Gratulując Organizatorkom sukcesu w stworzeniu tak owocnego i niezapomnianego wydarzenia intelektualnego, żywię głęboką nadzieję, iż również w przyszłym roku będzie miała miejsce w Sosnowcu równie udana i długo wspominana konferencja Przestrzenie Przekładu 4.

Patrycja Bobowska-Nastarzewska bobowska@umk.pl (Uniwersytet Mikołaja Kopernika w Toruniu) 